\title{
Humanitarian Intervention and the Changing Concepts of Sovereignty
}

\section{Dominika Švarc}

Dominika Švarc has graduated from Faculty of Law Ljubljana with the title LL.B..She has been a student of MSc Political Science at the American and World Studies program at the Faculty of Social Sciences Ljubljana and she is currently a PhD candidate at the same Faculty and a LL.M. candidate at the London School of Economics and Political Science. She has also been working as an independent legal advisor and researcher for the European Law Institute in Ljubljana and as an independent researcher for the South-European Comparative Law Institute.

ABSTRACT: U.N. Secretary General Kofi Annan recently observed that "state sovereignty, in its most basic sense, is being redefined ... by the forces of globalisation and international cooperation." The article deals with the question of how much this is an accurate observation in the context of humanitarian intervention. Within the theories of classical international law, the principle of nonintervention involves the prohibition to intervene in the internal affairs of a sovereign State. Even though there have always existed exemptions to this principle, there was never an exemption of humanitarian intervention mentioned, neither in the UN Charter or any other international legal instrument, nor in the customary law. In the article the possibility of new international legal norms evolving in this field is discussed, to justify intervention in the name of protecting fundamental human rights that are today one of the leading concepts of international legal order, tightly connected to the protection of international peace and security in a highly interdependent international community. To clarify the concept, some basic elements and dimensions of humanitarian intervention are outlined, together with some possible features of the future development of the humanitarian intervention concept. The aim of the article is to discover, what is, both in the legal sense and in practice, the relationship between the sovereignty of states and their responsibility to fulfil their obligations under the international law, including the obligation to respect and protect human life and dignity, as well as other fundamental human rights.

The contemporary political discourse often labels sovereignty as an emptied, irrelevant and sometimes even a disturbing category. For the international lawyer, these statements are unbearable and deserve a strong rejection. International law has emerged as the law of sovereign States. It has certainly never praised it as an absolute, nor a fundamental category. However, the concept of sovereignty has always been central to the history of interna- tional law and international relations. Today, as even the UN Secretary General Kofi Annan has observed, "state sovereignty, in its most basic sense, is being redefined... by the forces of globalisation and international cooperation". To discover if this is a truly accurate observation, it is fundamental that one understands the relevance of this concept in a rapidly changing context of the modern international community. A critical approach to the con- 
temporary discussion of the very concept of sovereignty, usually takes one of the two fundamental positions. The first approach considers international law as an apology of the State practice, whilst the other understands it as something normatively utopian. The apologetic approach should clearly be avoided, but at the same time, there might as well be too much normativism. International law was shaped by history and in this course of historical evolution; the sovereignty itself has recently faced at least two major challenges - the issue of international criminal jurisdiction and the problem of non-intervention. This article tends to deal with the latter, by discussing the nature and future of humanitarian intervention.

Within the theories of classical international law, the principle of nonintervention involves the prohibition to intervene in the internal affairs of a sovereign state. Nevertheless, there have always existed the exemptions to this prohibition. The international legal doctrine distinguished between the exemptions that are in themselves the law, and the exemptions, that are legally allowed for. The emergence of national states in the first twenty-five years of the UN has changed the course of these discussions. The 1970 Friendly Relations Declaration ${ }^{77}$ clearly considers any intervention a breach of international law. The UN Security Council is the only competent body to authorise the use of force in cases when international peace and

77 Declaration on Principles of International Law Concerning Friendly Relations and Cooperation among States in Accordance with the United Nations Charter (Friendly Relations Declaration), GA. Res. 2625 (XXV), U.N. Doc. A/8018 (1970) security are endangered or breached. Is this formulation outdated? At the time, it seemed that the development will strengthen the concept of sovereignty and the principle of nonintervention, turning it into an absolute imperative norm (ius cogens) of international law.

However, the expectations did not quite turn out that way. A number of international legal experts believe, that international practice, or international customary law has already amended the written law of non-intervention, specifically through the increasing resort to humanitarian intervention ${ }^{78}$. This principle was in general a valid reason for intervention in the 19th Century. It was not deemed wrong, at least not from the legal point of view, to use force by a state or a group of states in another country for the protection of some ethnic or religious community. However, this is mostly indifferent from the point of view of the present dilemma, since back then there were no international legal norms prohibiting the waging of war. Thus, it did not really matter how an armed intervention was justified. In the 20th Century package of international legal norms, expressly and absolutely prohibiting the use of force or the threat to use force in international relation, humanitarian intervention is by no means mentioned as an exception to that rule. Interestingly enough, even those states that used force for similar aims did not refer to their military operations as humanitarian intervention. Many realised only later, after the Kosovo crisis, that there had been

78 See e.g. Thürer, Daniel. 2000. Der KosovoKonflikt im Lichte des Völkerrechts: Von drei echten und scheinbaren - Dilemmata. Archiv des Völkerrechts, 38(1). 
other humanitarian interventions carried out before. At the beginning of the 21st Century, the positions are melting and the Security Council has itself contributed a great deal to the changing notions, by its actions. The cases of Somalia, Haiti, Rwanda and Albania provide examples of humanitarian intervention, though they were not called so at the time.

We can thus observe that at the beginning of the 21st Century, the positions are melting and the UN Security Council has itself contributed a great deal to the changing notions, by its actions. In case of Somalia (1992) and Haiti (1993) the Security Council authorised intervention in cases not so clearly involving a threat to or violation of international peace, nor were there any acts of aggression recognised. Somalia was facing a blast of a vast humanitarian crisis, but the Security Council itself has never argumented its decision on the matter, nor revealed the dimensions and elements that were threatening international peace in the particular case. It only provided for an ethical definition of "what by definition constitutes threat to international peace". In Haiti, the government was violently overthrown and that could consequently cause mass emigrations and flooding of refugees. Nevertheless, does the humanitarian crisis in itself constitute a threat to international peace? Couldn't it be that the Security Council thus opened a path for the States to intervene as they please in situations they deem similar and in which the Security Council refused / fails to react? On the other hand, should we maybe allow such developments to take place in the name of global security? Can security concerns override traditional notions of sovereignty? How do we reconcile new doctrines, such as the legitimate use of pre-emptive military force and regime change, which are couched in terms of democracy, security, and sovereignty in the modern international discourse?

The questions raised could be merged into two basic dimensions of the attempted refurbishment of sovereignty concepts. Firstly, what are the criteria that could and/or should stimulate intervention against a sovereign state, i.e., what are the moral, legal, security, and humanitarian bases of intervention? Secondly, who in the internationally community decides when these criteria have been met, when a certain threshold of behaviour has been passed that justifies intervention in the sovereign affairs of a nation state? Added to that might be another sub-question of maybe even greater importance - who is than to intervene? Are There New Norms of International Law Evolving?

International law rests on two legs. Codified law as represented by the UN Charter enshrines the principles of sovereignty and non-interference in the domestic affairs of a state, while customary law increasingly emphasizes the protection of human rights and the safety and well-being of the individual. Looking back at the Kosovo case, a spirited debate regarding the legality of the NATO action has not yet reached a conclusion. One view holds that, as there was no Security Council approval for NATO's use of force, the intervention was illegal according to black letter law. A contrary viewpoint out that Yugoslav violation of previous Security Council resolutions and a clear pattern of widespread human rights violations 
did, in the end, provides sufficient justification for the NATO action. When looking to the future, one must also consider the evolutionary nature of international law, of working to shape international law to help build a more peaceful global society.

However, before we go forth with the discussion about the basic parameters of humanitarian intervention in the contemporary security and sovereignty context, the observation must be made, that stricto sensu, the principle of humanitarian intervention has not yet become and maybe even cannot become part of new customary law for several reasons. However dynamic the interpretation of legal norms may be, the general prohibition of the use of force is considered a peremptory international legal norm (ius cogens) in both written law (the UN Charter) and customary law. Given its universal and absolute nature, it can only be changed by the international community as a whole (represented by the UN, not other institutions, such as NATO). That is to say, as long as the UN does not change more than halfcentury old international legal order, others may not change it either. The second reason is that an intervention, whose executors do not refer to the principle of humanitarian intervention, may not establish a new customary law. Regarding Kosovo, the NATO politicians did indeed speak about protecting human rights at stake, but none of them explicitly mentioned humanitarian intervention as the legal basis for intervention. This is strongly connected to the third reason, which is the lack of the so called opinio iuris, that is, the firm and certain belief of state that by their behaviour they wish to establish a new norm of customary law, or more legalistically said, that they clearly believe they act the way they do out of some legal (not merely moral) obligation. The states involved in the recent cases of intervention did not recognise the emergence of a new practice and, consequently, of a general norm of customary law. Finally, as long as some states executing intervention say that their practice establishes customary law while other opposes this practice, a new customary legal norm cannot come into being.

In the before mentioned cases of Haiti, Somalia, Rwanda and Albania, foreign forces were acting under explicit authorisation by the UN Security Council, and intervention in each case was thus lawful under international law. On the other hand, at the time of the Kosovo crisis, Moscow and Beijing were no longer willing to give their blessing to draft resolutions that would have authorised the use of force. Consequently, NATO acted without authorisation. There is no "third" way, once one or more permanent members of the Security Council have rejected the authorisation by the UN SC.

The Changing Concept of Humanitarian Intervention

The recent international legal order as it was shown - does not recognise the legality of military intervention even in case of genocide or ethnic cleansing. Thus, it would not allow an intervention to defend human rights either. There is no provision in the UN Charter or in any other international instrument for that matter, which would permit such an intervention. The international legal framework set in 1945 contained rather simple rigid rules. According to them, the UN Security Council may only use in selfdefence or on authorisation force. The 
purpose of and reasons for the use of force, and the enforcement of protected human rights were not distinguished. The Charter did not authorise the use of armed force by any state against another state for the protection of human rights or establishment of democratic institutions (like in the case of Iraqi war - 2003), or for any other cause. Therefore, the conclusion here could be that no new norm is emerging in the recent international legal order, which would recognise the legality of either form of humanitarian intervention.

However, in the 20 the Century, international law seemed to reach the point of evolution where the protection of human life and dignity constitutes its most fundamental element. It is possible to say that there is a slight contradiction between these to principles the principle of non-intervention and the principle of protecting human rights, since the reality often prevents the latter without breaching the former principle. It seems that some critics might be right to criticise international legal order to be deaf to the tones of reality and helpless when its fundamental principles collide. The current absolute (imperative) legal norm of non-intervention thus paralyses any protection of basic human rights from an outside force other than those acting explicitly with the UN SC blessing. The natural question follows what if the Security Council fails or refuses to act. The current mechanism of UN SC voting clearly leads to an even greater chance of such outcome. How can the international community, a state or a group of states step aside in cases of mass murders, state terror and torture? Furthermore, the concept of state responsibility to fulfil their obligations under international law (including those to protect international peace and security; to recognise, respect and protect fundamental human rights) also calls for a refurbishment of our notions on the nonintervention principle. For that reason, at least some developments must be also made in the direction of changing the understanding and the legal reality of humanitarian intervention.

As a needed step in this direction, there is much discussion of the wisdom of changing the parameters and terminology of the debate. Above all this means making states and governments more accountable for their actions vis-à-vis their citizens, so that the issue becomes one of a responsibility to protect on the part of states, rather than a right to intervene on the part of the international community. Similarly, humanitarian intervention becomes rather protective intervention when states and governments have failed their responsibility. For its part, however, the international community has the responsibility to assist states and governments in providing the means by which fundamental human rights can be assured in the first place, before intervention becomes necessary, and then to adequately follow up in post-conflict reconciliation and reconstruction should intervention occur - in short, full cycle involvement.

Issues of Legitimacy

More thought needs to be given to the why is of intervention, the criteria that should be met to justify intervention in order to help pinpoint where international law and custom should be evolving. Delineating such criteria could also help establish common ground between quite divergent international perspectives on the relative 
weight to be given to sovereignty $\mathrm{v}$. intervention, thus ensuring that when intervention occurs, it has the widest international support. Following some discussions, four possible categories of criteria justifying intervention, from the easiest to the most difficult, could be set out:

- Gross and systematic human rights abuses, including genocide (such as occurred in Cambodia and Rwanda);

- The suppression of the clearly demonstrated will of the majority (such as the overthrow of the democratically-elected government in Haiti or the suppression of an internationally-mandated expression of selfdetermination, as in East Timor);

- Clear cases of failed states, where central authority is nonfunctioning and the civilian population is at the mercy of militias, warlords, criminal gangs, etc. (Somalia, Liberia, Sierra Leone);

- The illegal and inhumane use of power by one side or the other during a civil war encompassing an attempt at secession and/or ethnic/religious self-determination.

The obvious difficulty with these categories is that evidence of the criteria in question is not always clear-cut and that grey areas can exist within a category (when does widespread civil strife become a failed state?), and that some cases fall into more than one category.

One way of considering the legitimacy of humanitarian interventions is to place such interventions along a consensual/coercive continuum. Speaking in words of historical examples, intervention in Sierra Leone poses no problem concerning legitimacy, as the government in Freetown requested in- ternational aid. Regarding East Timor, the consent of the Indonesian government was granted, albeit following strong international diplomatic and economic coercion. Kosovo represents the most difficult case. While not legitimate in the narrow sense of not having the approval of a direct mandate from the UN Security Council, the Kosovo intervention was attempted to be justified by NATO on primarily humanitarian grounds. These were amplified in public only by the British government, which refuted the accusation of illegitimacy by pointing to the framing authority of past UN SC resolutions on Yugoslavia as well as to the six non-aligned states in the Security Council which joined western nations in voting against the Russian resolution (condemning the NATO action), which could be taken as implicit approval. The wider international response was either sympathetic or muted.

\section{The Modalities of Intervention}

The current international environment, as said before, is not at all conducive to well-planned, well-carried out, well-supported interventions that can stay the course. Especially in a period of generalised retreat from multilateral institutions, the re-empowerment of state agency may, while seeming a paradox, be all the more important in terms of strengthening notions of a responsibility to protect.

Five categories of the modalities of intervention can be reviewed in the course of current international reality: 1. conflict prevention;

2. sanctions, where there are more problems than opportunities, and where it's difficult to show causal effect and avoid injuring the innocent; 
3. legal instruments, where definitions of sovereignty are conditional on norms developed through the Nürenberg, Yugoslav and Rwanda tribunals, by the International Criminal Court, by legal intrusion into the conduct of military operations; and by expanding case law that provides for domestic jurisdiction over international behaviour;

4. military intervention, of three types: (a) coalition action without a direct UN mandate (Kosovo); (b) a UN SC mandate with a framework nation in the lead (Australia in East Timor); and (c) an independently legitimated action to rescue and restore a UN effort (the UK in Sierra Leone);

5. Full cycle planning, noting how strategic opportunities created by military interventions have been squandered by lack of post-conflict administration and reconstruction (Angola, East Timor, Kosovo) ${ }^{79}$.

Who Intervenes, and Why?

While the United Nations is best positioned to give legitimacy to interventions, too often UN SC action is blocked by a great power veto. One solution to this could be the concept of a negative veto, where action will be taken unless a veto is cast, making it more difficult for countries to block action. In the absence of such reforms, what other sources of authority can we look to provide legitimacy for intervention?

Certainly regional organizations can, and have, taken the lead. Regarding the Organization of American States (OAS), there is the triggering mechanism provided by the Santiago Decla-

79 Intervention, Sovereignty and International Security, avaliable at

http://www.pugwash.org/reports/rc/rcllhtm ration of 1991 regarding military overthrows of a democratically elected government. Yet regional politics can militate against regional solutions; in the cases of El Salvador and Guatemala, countries in Latin America expressed a preference for having the international community, not regional organizations, intervene. Regarding Africa, even though non-interference is enshrined in the OAU charter, there have been cases of the OAU being willing to give primacy to intervention over sovereignty (especially in the case of South African apartheid).

Regarding domestic politics and the national interest, domestic considerations can both propel and constrain intervention. Indeed, some semblance of a "national interest' must be present for a country to commit troops and resources to an intervention. In the case of the US and Haiti, for example, it was argued that several important national issues helped justify US intervention: Haitian refugees, the Congressional black caucus, and the affront to US power when the USS Harlan was turned away from Haiti's shores. As in the case of Somalia, of course, events can also conspire to constrain and ultimately terminate an intervention.

While there does seem to be convergence within the international community on criteria for intervening in the case of gross human rights abuses, the problem is one of agencies and modalities. There is thus a need to come back to issues of world governance and new concepts of security. While recognizing the need to avoid invidious double standards, a distinction (in terms of global security) can be made between instability in Bosnia and Kosovo and those in a country 
like Rwanda. Such threats to global security are also present from current and potential conflict in and around the former Soviet Union, China, and India, (the three countries most opposed to intervention). To that end, unilateralist sentiments such as are being seen in the US will create difficulties for consensus building, especially with Russia, China and India.

The "Effectiveness of Intervention" Debate

A strictly utilitarian approach to judging a 'successful' intervention could be based on the prospects of: 1) the number of lives saved; and 2) whether the intervention helps create postconflict political stability. An obvious question here is - how will you know how many lives you have saved? Kosovo could be an example of more lives being lost because of the NATO operation.

To prevent, what ultimately turns out to be the criteria for successful intervention - the goals and strategy of the intervener(s) themselves, there is need to ensure that the original rationale for intervention does not change during the intervention itself. However, sometimes avoiding that outcome could mean that the job is not done. In the case of Iraq, not finishing the job has meant continued oppression of Kurds and Shi'a and continued international intervention in Iraq. The outcomes of the latest intervention in Iraq are yet to be crystallised.

When it comes to creating political stability, how long is the time line by which an intervention is judged? The Bosnia intervention could be called successful, but is it irreversible? Issues such as the return of refugees are very complex and not always handled well by international community. It could be said that the right of return is essential to the long-term success of an intervention (e.g., Dayton will fail otherwise). Yet, the right of return has two inherent problems: establishing the status-quo-ante may not be the preferable solution, and taking away someone's refugee status by telling him/her that they can now go home (especially if there is no effective policing and no individual security to return to) could expose such returnees to danger. Post-conflict cooperation with local authorities is also a delicate issue.

\section{Sanctions and Intervention}

The use of sanctions as a tool short of military intervention (application of Chapter VI and Article 41 - Chapter VII of UN Charter), is also an important part of the discussion at stake. The fact that 250,000 children have died in Iraq in the past over a decade, partly because of international sanctions, demonstrates the need for ways of making sanctions more 'humanitarian.'

Yet on the other hand, targeted sanctions, aimed at political leaders, elites, and governments (freezing assets of Iraq, EC diplomatic ban on Burma) have been difficult to make effective. Authoritarian regimes have too much leeway in determining the internal allocation of resources, and thus can largely avoid the impact of sanctions. In addition, the effectiveness of sanctions is often diminished by the behaviour of some states, ignoring the SC resolutions and not respecting the sanctions established by the SC. Whilst all the UN member states are explicitly obliged under the Charter to enforce the SC resolutions (accepted under the Chapter VII of the Charter), there is no such (legal) obligation on 
the non-member states. Though the SC often calls upon those states to help the UN carrying out the sanctions imposed, their refusal to do so, strongly affects the success of the sanctions.

At the same time, military capability is employed against a wide range of objectives (including communications), and at times sanctions can entail more suffering than military force, so a continuum from one to another is not always obvious.

The international community needs to focus on modalities of non-violent humanitarian intervention, while recognizing that these will not solve emergencies of mass killing such as occurred in East Pakistan, Cambodia, and Rwanda.

In contemporary discussions on this issue, six principles are repeatedly enumerated in defence of the use of force $^{80}$ :

1. Just cause (supreme humanitarian emergency - "shock to the conscience of mankind");

2. Last resort, exhausting peaceful solutions (but not in a drawn-out continuum), never forgetting that the use of force will always produce some harmful effects;

3. Seek to end the catastrophe as quickly as possible;

4. Non-combat immunity as the sine qua non of proportionality;

5. Right intention (while recognizing that beneficial outcomes can be produced from non-humanitarian intentions, e.g., Vietnam's intervention in Cambodia);

80 See e.g. Intervention and Military Force, report of the Pugwash Conference Working Group, avaliable at

http://www.pugwash.org/reports
6. Reasonable prospect of success (both saving the victims and putting in place structures to safeguard rights, though this will be very difficult to do).

International Perspectives on Intervention

Equally significant in thinking about humanitarian intervention is the fact that the world could well be moving into a period of renewed strategic rivalry, marked by a renewal of individual state power, a reduced reliance on multilateral institutions, and the return of nuclear weapons in global politics (the latter stimulated by a growing US-China rivalry, nuclear proliferation concerns and US choices about dealing with those concerns, and nuclear weapons being a logical choice for countries wanting to forestall intervention against them).

Given the difficulty of establishing criteria, and the divergent political, cultural, and ideological views on intervention vs. sovereignty, there is a real need for airing the fundamental disagreements between countries on what is legitimate intervention.

Many non-western states essentially see interventionism of western states as neo-colonialist. The concept of intervention can be either viewed as positive (giving a helping hand) or negative (interference) by different actors involved or simply by different parts of the world. Likewise, the concept of human rights is viewed differently around the world, encompassing both the individual and the collective society. Regarding human rights, these include not only individual freedoms but also social goods such as equitable living conditions and access to health care. In recent times, interventions have caused widespread and lasting 
damage to society (e.g., Iraq, Afghanistan). Human rights abuses are not unknown in western countries, are these grounds for intervention? Finally, intervention is a tool of the powerful. Weak states cannot intervene, thus they must rely on sovereignty. Hence the apprehension in some parts of the world that the "new interventionism" is based mainly on western values of human rights.

Yet, it must be observed that many international interventions have not been aimed at either the territorial integrity or the political independence of the state in question (e.g., the no-fly zone in Iraq, the Kosovars in Yugoslavia), at what might be called the fundamental elements of sovereignty. Rather, such interventions have sought to compel a change in behaviour regarding widespread abuses of human rights (Kurds and Kosovars).

The Future of Humanitarian Intervention

The UN has been heavily criticized for flawed outcomes that stem from flawed interventions (whether military or non-military). Yet the UN has to deal with inherently unstable regions, where conflict/post-conflict is not a continuum but a cycle. The organization is often called on to respond with insufficient notice (the post-conflict Kosovo situation was dumped on the UN with 3 weeks notice); insufficient funds; and inequality in funding (Kosovo v. Sierra Leone). There are also the difficulties of coordination within the UN and between UN agencies and NGOs (there were some 200 in Kosovo shortly after the end of conflict) and the manipulation of the international community by warring parties. Looking at the case of Africa, there is now 40 years of intervention experi- ence on the continent, but little in the way of lessons learned and strategizing on how to do it better. Issues of governance are critical to conflict prevention in Africa, of people focusing on what their governments can do for them, of holding governments accountable. Once conflict does break out, there will be no quick fixes, and so be wary of rushing into a truce that will break down. While conflict prevention is necessarily a long-term strategy, this is where the focus should be: democratization, accountability, transparency, good governance. In support of these goals, some coercion (diplomatic, economic) on the part of the international community will be necessary.

In terms of the way forward, there is an often-discussed need to reconcile intervention principles and procedures, while recognizing that intervention issues are drivers of international relations can either facilitate cooperation or sharpen tensions between the major powers, between, and within different regions. Regarding how to intervene, five components are thought to be essential: assess the objectives; assess the setting and actors involved; assess options; maintain solidarity among the coalition of the willing; and do no harm and stay the course. Problems remain, however, of how to turn substantive principles into procedures for action of providing practical policy guidance on articulating principles and procedures for intervention.

The difficulty of transforming principles into practical policy guidelines is obvious, but such an exercise is important in promoting convergence on these issues between the great powers, differing regions, and different global 
constituencies (security, development, human rights communities). Also important is the effort to think about concepts of national interest that incorporate individual rights and the dangers posed by failed states that can help strengthen the case for intervention, where needed.

These issues should also be set in a global governance framework, where intervention and human rights protection affect issues managing strategic rivalry, UN reform and effectiveness, mal-distribution of resources, and trans-national civil society.

\section{Conclusion}

It must be acknowledge that many people see using military force in defence of humanitarian aims as an oxymoron. Nonetheless, the enumeration of principles that can guide the use of military force is important not just to shape policy but in the setting of benchmarks for outside evaluation of the use of force by publics, media, NGOs, etc., all of whom should hold the intervener accountable. The issue of non-combat immunity is also problematic, as we might have learned bitterly from the Yugoslav example, in that hitting civilian targets hard early in the Yugoslav campaign might have ended the war earlier, thus reducing overall civilian casualties and adhering to the principle of proportionality. In the end, international norms might evolve so to more widely enable intervention, but they still will not guarantee it. Thus, it is all the more important to place the defence of human rights and values as being in both the national interest and a prime responsibility of states. Regarding the future, it is likely that the international community will continue to face two practical alternatives: those cases where it can intervene (Bosnia, Kosovo, and East Timor) and those cases where it cannot (Chechnya, Tibet). We should not downplay the hard task of consensus building and of intervention achieving widespread political legitimacy, which is juxtaposed with the larger problem of losing the post-Cold War peace, deteriorating relations between the West and Russia and China, and the possibility of state failure on a much larger level.

Further, it can be noted that the concepts of state sovereignty and individual human rights are evolving, and even more, in a way they have been integrated since their origins in the 12 th century. What is somewhat new here is the concept of international security, beginning with League of $\mathrm{Na}-$ tions in 1919, and evolving through the 20th century? What China, Cuba, North Korea, and others defend is a concept of absolute sovereignty, but sovereignty has never been absolute. In western countries, sovereignty is maligned by stressing its negative connotations, but sovereignty is a positive concept when grounded in equality (extending to both territory and the individual). Human rights in both international law and the UN charter have now become a "major legal net" of rules, procedures, statutes, albeit of a different character than the body of international law surrounding sovereignty.

The problem should not be seen as one of intervention per se, but of continued tension between sovereignty and intervention and the fact that intervention only takes place in countries where state structures are eroding: i.e., in developing countries, in precisely those countries that need sovereignty the most. Needed here are steps to 
support the state-building process. Intervention should be seen as a rare contingency; the less it has used, the more successful and stable the international community. Stable states are important as well because the very decision to intervene is a sovereign decision (in terms of contributing troops and funds to peacekeeping missions). Problems arise with the tendency of powerful states to export their values, however worthy, through illegitimate means (e.g., the messianism of the French Revolution in exporting democracy). Comparisons today would be countries exporting free-market and democratic values through trading policies (globalisation) or through military mean (the recent US led war in Iraq); noteworthy ends not always implemented by legitimate means.
It is possible that States will still give priority to their many internal problems created by interstate rivalries and the flaws of globalisation. The international community risks being squeezed between a new Scylla and Charybdis. The Charybdis being a universal intervention, unilaterally decided by the leaders of just one or a few superpowers who are convinced that they have found a global mission provided by some global threat. The Scylla is resignation to universal chaos in the form of new and even more catastrophic abuses of human rights, fresh humanitarian disasters, or regional wars that risk escalation. Only through wise judgment can the path between them be charted.

\section{References:}

Intervention, Sovereignty and International Security. Available at: http://www.pugwash.org/reports/rc/rc11htm

Barry, Tom. 2002. US Foreign Policy: Shaping Global Affairs. Available at: http://www.fpif.org/commentary/2002/0207jingoism.html 104-115

Hoffman, Stanley. 2002. The Clash of Globalizations. Foreign Affairs 81(4):

Jackson, John H. Sovereignty-Modern: A New Approach to an Outdated Concept

Pollack, Kenneth M. 2002. Next Stop Baghdad? Foreign Affairs 81(2): 3247

Thürer, Daniel. 2000. Der Kosovo-Konflikt im Lichte des Völkerrechts: Von drei - echten und scheinbaren - Dilemmata. Archiv des Völkerrechts, 38(1)

Valki, Lázslo. 2003. Consequences of 9/11: Emergence of New Norms in International Law? 2nd Pugwash Workshop on Terrorism, Como, Italy, 9-12 October 2003 